How to cite: Kubiak-Wójcicka, K. (2019) Long-Term Variability of Runoff of Vistula River in 1951-2015. 2019

"Air and Water - Components of the Environment" Conference Proceedings, Cluj-Napoca, Romania, p. 109-120,

DOI: $10.24193 / A W C 2019 \_11$.

\title{
LONG-TERM VARIABILITY OF RUNOFF OF VISTULA RIVER IN 1951-2015
}

\author{
Katarzyna KUBIAK-WÓJCICKA ${ }^{1}$ 凹
}

DOI: 10.24193/AWC2019_11

\begin{abstract}
This study presents the characteristics of the Vistula River runoff in the perspective of many years. Based on the daily values of Vistula flows for 9 selected hydrological stations located along the course of the river, analysis of the long-term variability of flows in hydrological years 1951-2015 was made. The work analyzes the variability of maximum, average and minimum annual flows. The highest annual flows occurred in 2010 and 1975, while the lowest in 1954, 1984 and 2012. Over the analyzed period, the difference between maximum and minimum flows has been reduced. The amplitude of annual flows demonstrates a clear downward trend. On the basis of the values of average annual flows, a hydrological classification was made, in which dry, normal and wet years were determined based on the coefficients $\mathrm{k}$ and sum $(\mathrm{k}-1)$. Normal years are characterized by average annual flows equal to or close to the average value over many years (the coefficient $\mathrm{k}$ is from 0.91 to 1.1$)$. It was established that dry years predominate $(\mathrm{k}<0.9)$ over wet years $(\mathrm{k}>1.1)$. Depending on the hydrological stations, dry years were found from 22 to 29 times over the analyzed 65 years, and wet years from 15 to 23 times. Only in Tczew (the mouth of the Vistula River), both wet and dry years were found 22 times.
\end{abstract}

Keywords: runoff variability, Vistula river, Poland

\section{INTRODUCTION}

One of the greatest challenges recognized in the whole world is a growing pressure on water resources resulting from climate changes and human activity. In the recent years, there have been a number of studies conducted on the influence of climate change on water resources (Pekarova et al., 2006; Stahl et al., 2010; Dobrovol'skii, 2018). In the literature on the subject, one may find publications regarding projections of future climate changes for the region of Europe (IPCC 2013; Alfieri et al., 2018). Climate predictions for Poland expect further warming and continuation of already observed changes in amounts of precipitation and precipitation's spatial and seasonal distribution (Szwed et al., 2010; Osuch et al., 2016). Precipitation and air temperature are considered the main factors that are driving the hydrological changes. Spatial and temporal changes of river runoff have been noted in many regions of Europe. Studies on the runoff variability as one of the most important components of water circulation have been done for the following

\footnotetext{
${ }^{1}$ Nicolaus Copernicus University, Faculty of Earth Sciences, Lwowska 1, 87-100 Toruń, Poland, email:kubiak@umk.pl
} 
regions of Europe: Germany (Bormann, 2010), Czechia (Hanel et al., 2012), Lithuania (Stonevičius et al., 2014), Croatia (Barbalić and Kuspilić, 2014), Romania (Romanescu and Zaharia, 2016).

Detection of river discharge changes trends in Polish conditions have been done mainly in rivers with small and medium basins, and relatively unchanged discharge regime (semi-natural and natural basins) (Kędra, 2017; Piniewski et al., 2018). Determination of discharge variability in basins of large rivers and detection of main causes of discharge changes is exceptionally hard due to the influence of not only meteorological conditions but also anthropogenic which take place on significantly large portion of the river basin. Such studies were conducted by by Jokiel and Stanisławczyk (2012), Kubiak-Wójcicka and Bąk (2018), Wrzesiński and Sobkowiak (2018) and also on large European rivers (Sánchez-Chóliz and Sarasa, 2015; Pfeiffer and Ionita, 2017; Orešić et al., 2017). From the practical point of view, determination of discharge of large rivers, which comprise an important reserve of surface water, is extraordinarily important because water resources are extensively used by various branches of the national economy (industry, agriculture, public utilities). Knowledge of discharge regime and assessment of influence of its changes on discharge volume has a substantial meaning to strategic management of water resources within whole river basin.

From the economic point of view, it is important to know river discharge, its availability throughout a year and possibility to use it for economic purposes. Bearing in mind limited water resources in Poland, it is exceptionally important from the economic point of view to determine temporal variability of water resources in both, multi-year and seasonal periods. Thanks to that knowledge it is possible to accommodate to the changes and ensure sufficient water amount during both dry and wet years.

The aim of this paper is to study the variability and dynamics of river discharge by determination of trends and indices of discharge variability in multi-year perspective. The analysis has been conducted on the basis of annual average values of River Vistula discharge collected from the selected gauging stations along the river in hydrological multi-year period of 1951-2015. Assessment of forming of hydrological regime of River Vistula on its whole stretch has been conducted taking into consideration the variability of precipitation and air temperature in the scale of the basin.

\section{DATA AND METHODS}

\subsection{Study area}

The study covers Vistula River, the largest river in Poland and the second largest river basin in Baltic Sea's catchment area. Its total length is $1022 \mathrm{~km}$. The river basin area calculated down to the hydrological station in Tczew is $194376 \mathrm{~km}^{2}$. The largest right side tributaries include Dunajec, Wisłoka, San, Wieprz, Bug with Narew, Drwęca, and the largest left side tributaries include Pilica, Bzura and Brda (Fig. 1). Vistula has meridional river channel pattern, from the south to the north. The river's 
sources are located at slopes of Barania Góra at altitude $1106 \mathrm{~m}$ a.s.l. and it flows into Baltic Sea creating a delta at Vistula Żuławy (marshlands).

There are only two artificial water reservoirs located on the Vistula River: Goczałkowice at its upper course and Włocławek at its lower course. The largest reservoirs located at Vistula's tributaries include Solina Reservoir on River San, Czorsztyn Reservoir and Rożnowo Reservoir on River Dunajec and Porąbka and Tresna on River Soła.

There are 19 hydrological stations located along the whole Vistula's stretch, which carry on hydrological measurements. The research that comprises a base for this paper used the data collected from 8 of them. The choice was made on the basis of availability and length of recorded data (at least 50 years) as well as on location of particular stations on the Vistula's course. As Kundzewicz and Robson (2004) suggest, only a long data series and appropriate gauging station location comprise a solid documentation for detection of hydrological changes. The selected gauging stations are: Szczucin, Sandomierz, Annopol, Dęblin, Warszawa, Włocławek, Toruń, Tczew.

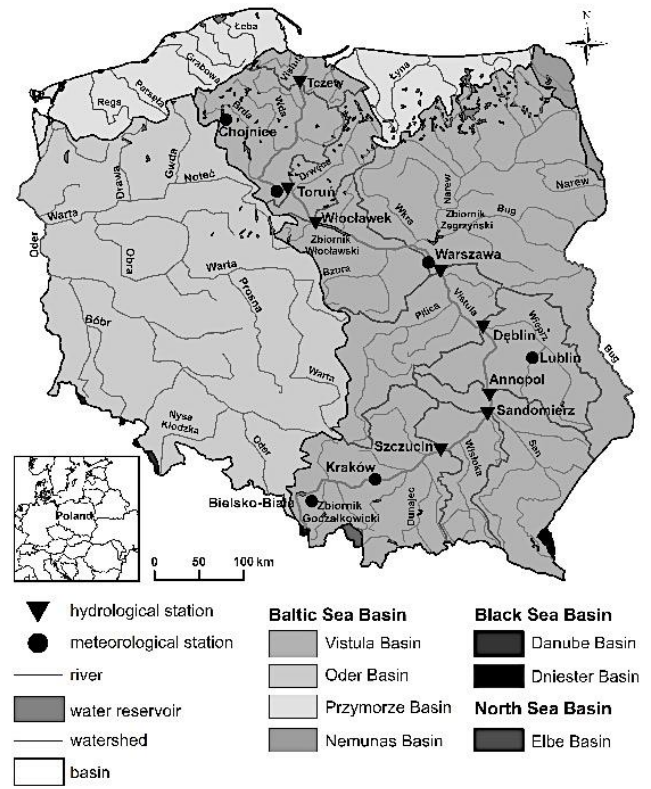

Fig. 1. Study area

Vistula River basin can be divided into three parts:

- Upper Vistula ends at San estuary and its area within borders of Poland is $45874 \mathrm{~km}^{2}$. This area is characterized by the largest precipitation (from 700 to 1000 $\mathrm{mm}$ in upper parts of the mountains). There are three hydrological stations: Kraków, Sandomierz and Annopol and two meteorological stations: Kraków and Bielsko-Biała, located there.

- Middle Vistula ends at combined estuaries of Bug and Narew. The area of Middle Vistula basin within borders of Poland is $88765 \mathrm{~km}^{2}$. Precipitation sums total up from $500 \mathrm{~mm}$ in lowland part to 600 in upland and lakeland parts of it. Hydrological data at this area has been collected from two hydrological stations: Dęblin and Warsaw and the meteorological data - from meteorological stations Lublin and Warsaw.

- Lower Vistula - from estuary of Narew to Baltic Sea - with the smallest basin area of $34136 \mathrm{~km}^{2}$. Precipitation on this area reaches from 500 to $600 \mathrm{~mm}$, with predominant lowlands with low precipitation. At this part, there have been selected three hydrological stations: Włocławek, Toruń and Tczew, and two meteorological stations: Torun and Chojnice.

Average annual precipitation values at meteorological stations located upper and middle parts of Vistula basin (stations Kraków, Bielsko-Biała and Lublin) in the multi-year period 1981-2015 were lower than in the periods 1951-1980 and 1951-2015 (Table 1). 
Table 1. Average annual precipitation and air temperature on the selected meteorological stations

\begin{tabular}{|l|r|r|r|r|r|r|}
\hline \multirow{2}{*}{$\begin{array}{c}\text { Meteorological } \\
\text { station }\end{array}$} & \multicolumn{3}{|c|}{ Average air temperature $\left({ }^{\circ} \mathbf{C}\right)$} & \multicolumn{3}{c|}{ Average annual precipitation (mm) } \\
\cline { 2 - 7 } & $\mathbf{1 9 5 1 - 1 9 8 0}$ & $\mathbf{1 9 8 1 - 2 0 1 5}$ & $\mathbf{1 9 5 1 - 2 0 1 5}$ & $\mathbf{1 9 5 1 - 1 9 8 0}$ & $\mathbf{1 9 8 1 - 2 0 1 5}$ & $\mathbf{1 9 5 1 - 2 0 1 5}$ \\
\hline Kraków & 7.8 & 8.6 & 8.2 & 675.3 & 661.7 & 668.0 \\
\hline Bielsko-Biała & 7.8 & 8.6 & 8.2 & 1016.1 & 965.3 & 988.7 \\
\hline Lublin & 7.5 & 7.9 & 7.7 & 597.5 & 576.6 & 586.2 \\
\hline Warszawa & 7.8 & 8.6 & 8.2 & 507.8 & 532.1 & 520.9 \\
\hline Toruń & 7.7 & 8.6 & 8.2 & 525.0 & 529.7 & 527.5 \\
\hline Chojnice & 6.9 & 7.7 & 7.4 & 566.7 & 580.5 & 574.1 \\
\hline
\end{tabular}

In turn, annual average precipitation in the middle part of the basin (Warsaw) and the lower part (Torun and Chojnice) in the period 1981-2015 were higher than annual average values in periods 1951-1980 and 1951-2015. In case of average annual air temperature, the period 1981-2015 was significantly warmer than the period 19512015. The period 1951-1980 was significantly cooler than the periods 1981-2015 and 1951-2015, which was observed on all of the analyzed meteorological stations.

In the case of Vistula's annual discharge values, the period 1981-2015 characterizes by lower maximum discharges (except for Szczucin), lower average values and higher minimal discharges on most of the gauging stations, as compared to the period 1951-2015 (Table 2).

Table 2. Characteristics of specific discharges of Vistula

\begin{tabular}{|c|c|c|c|c|c|c|}
\hline $\begin{array}{c}\text { Hydrometric } \\
\text { station }\end{array}$ & $\begin{array}{c}\text { Basin area } \\
\left(\mathbf{k m}^{2}\right)\end{array}$ & $\begin{array}{c}\text { Period of } \\
\text { observations }\end{array}$ & $\begin{array}{l}\text { WWQ } \\
\left(\mathrm{m}^{3} / \mathbf{s}\right)\end{array}$ & $\begin{array}{c}\text { SSQ } \\
\left(\mathbf{m}^{3} / \mathbf{s}\right)\end{array}$ & $\begin{array}{l}\text { NNQ } \\
\left(\mathrm{m}^{3} / \mathbf{s}\right)\end{array}$ & $\begin{array}{c}\mathbf{S S q} \\
\left(\mathbf{l} / \mathbf{s k m}^{2}\right)\end{array}$ \\
\hline \multirow{3}{*}{ Szczucin } & \multirow{3}{*}{23876.75} & $1951-1980$ & 4440 & 242 & 40.5 & 10.10 \\
\hline & & $1981-2015$ & 5010 & 228 & 60.9 & 9.56 \\
\hline & & 1951-2015 & 5010 & 239 & 40.5 & 9.99 \\
\hline \multirow{3}{*}{ Sandomierz } & \multirow{3}{*}{31810.27} & 1951-1980 & 5040 & 303 & 57.0 & 9.53 \\
\hline & & $1981-2015$ & 4470 & 281 & 72.0 & 8.84 \\
\hline & & $1951-2015$ & 5040 & 295 & 57.0 & 9.26 \\
\hline \multirow{3}{*}{ Annopol } & \multirow{3}{*}{51498.94} & 1951-1980 & 6010 & 456 & 96.0 & 8.86 \\
\hline & & $1981-2015$ & 5350 & 418 & 92.0 & 8.11 \\
\hline & & $1951-2015$ & 6010 & 439 & 92.0 & 8.53 \\
\hline \multirow{3}{*}{ Dęblin } & \multirow{3}{*}{68327.34} & 1951-1980 & 6000 & 541 & 116 & 7.92 \\
\hline & & $1981-2015$ & 5440 & 482 & 114 & 7.06 \\
\hline & & 1951-2015 & 6000 & 510 & 114 & 7.46 \\
\hline \multirow{3}{*}{ Warszawa } & \multirow{3}{*}{84640.60} & $1951-1980$ & 5570 & 600 & 112 & 7.08 \\
\hline & & $1981-2015$ & 5740 & 553 & 149 & 6.53 \\
\hline & & $1951-2015$ & 5740 & 579 & 112 & 6.84 \\
\hline \multirow{3}{*}{ Włoclawek } & \multirow{3}{*}{171763.42} & $1961-1980$ & 6920 & 1018 & 185 & 5.93 \\
\hline & & $1981-2015$ & 6540 & 869 & 160 & 5.06 \\
\hline & & $1961-2015$ & 6920 & 918 & 160 & 5.34 \\
\hline \multirow{3}{*}{ Toruń } & \multirow{3}{*}{180390.67} & $1951-1980$ & 6650 & 1014 & 234 & 5.62 \\
\hline & & $1981-2015$ & 6190 & 944 & 218 & 5.23 \\
\hline & & $1951-2015$ & 6650 & 986 & 218 & 5.46 \\
\hline \multirow{3}{*}{ Tczew } & \multirow{3}{*}{193806.46} & $1951-1980$ & 6430 & 1072 & 264 & 5.53 \\
\hline & & $1981-2015$ & 6360 & 1020 & 266 & 5.26 \\
\hline & & 1951-2015 & 6430 & 1044 & 264 & 5.39 \\
\hline
\end{tabular}

Note: WWQ - the highest discharge in the period, NNQ - the lowest discharge, SSQ - average discharge, SSq - average specific runoff in the period, $\alpha$-irregularity coefficient 
Particular parts of Vistula basin have various water abundance, which is described by specific runoff. It's volume of water that has flown within 1 second from an area of 1 square kilometer of the basin. The largest abundance characterizes the upper part of the Vistula basin (specific runoff between 8 and $10 \mathrm{l} / \mathrm{s}_{\mathrm{km}}{ }^{2}$ ). In the middle part of the basin, specific runoff is lower and varies from 6.5 to $81 / \mathrm{skm}^{2}$, and in the lower part of the basin it is 5 to $61 / \mathrm{s} \mathrm{km}^{2}$. Among the analyzed three periods: 1951-2015, 1951-1980 and 1981-2015, the highest water abundance was in the period 1951-1980.

\subsection{Methods}

The analysis has been conducted on the basis of daily values of Vistula discharge recorded at 8 hydrological stations (Szczucin, Sandomierz, Annopol, Dęblin, Warsaw, Włocławek, Toruń and Tczew). In order to characterize meteorological conditions, there have been used daily values of precipitation and air temperature at 6 meteorological stations: Kraków, Bielsko-Biała, Lublin, Warszawa, Toruń and Chojnice. Both hydrological and meteorological data have been provided by the Institute of Meteorology and Water Management - National Research Institute (IMGW - PIB) and include long data series, i.e. hydrological years 1951-2015. Hydrological year in Poland begins on November $1^{\text {st }}$ and ends on October $30^{\text {th }}$ next year.

In order to characterize discharge volume, precipitation and air temperature, statistical calculations were made. Based on daily values, there have been determined maximum, minimum and average values in periods of months, years and multi-years, with use of MS Excel spreadsheet.

The assessment of discharge variability has been conducted in multi-year time frame. On the basis of its results, there have been identified the highest and the lowest discharge values in the whole multi-year period. Moreover, dry and wet years have been determined, in which average annual discharges significantly varied from multi-year averages. The calculations utilized the index $\mathrm{k}$, which is an average discharge in a given year (Qi) relative to average discharge in the whole multi-year period (Qsr).

It was extensively used in many scientific studies in order to determine so called wet years $(\mathrm{k}>1)$ and dry years $(\mathrm{k}<1)(K \operatorname{lavinšs~et~al.,~2008;~Gailiušis~et~al.,~2011;~}$ Kubiak-Wójcicka, 2018). In order to determine discharge variability, there have been a number of hydrological indices used: irregularity coefficient $\alpha$, variability index $(\mathrm{Cv})$, flashiness index RBI and trend of annual discharges in multi-year period, which is commonly used for hydrological rivers characteristics (Kliment and Matoušková, 2008). The irregularity coefficient is the quotient of the maximum flow to the minimum during the year. The variation coefficient $\mathrm{Cv}$ is the quotient of the standard deviation and the arithmetic mean of flows during the year. Flashiness index (RBI) helps in determination of frequency and short-term speed (day by day) of discharge changes. This index has been determined by Baker et al. (2004), and after 
its inventors is called the R-B Index (or RBI). This index has been calculated with the following formula [1]:

$$
\begin{array}{ll}
\text { RBindex }= & \frac{\sum_{i=1}^{n}\left|q_{i}-q_{i-1}\right|}{\sum_{i=1}^{n} q_{i}} \\
\text { where: } & q-\text { average daily discharge, } \\
& i-\text { day, } n=365(366)
\end{array}
$$

The RBI is a dimensionless index, and it fits the range of 0 to 2 (Holko et al., 2011). Zero represents constant discharge while lager index values indicate increased discharge frequency (Královec et al., 2016).

\section{RESULTS AND DISCUSSIONS}

\subsection{Precipitation and air temperature in years 1951-2015}

The analysis of average monthly precipitation and air temperature has been conducted in 6 meteorological stations. The figures 2, 3 and 4 present just three selected stations (Kraków, Warsaw and Chojnice), which are representative for particular parts of River Vistula.

On meteorological stations in Kraków (Fig. 2) and Bielsko-Biała (upper course of Vistula) there is a clear upward trend in average annual air temperature, in the analyzed multi-year period 1951-2015. Particularly large increase has been recorded in the period 1981-2015, while in the period 1951-1980 the temperature experienced small downward trend. Annual precipitation sums in turn, do not display significant upward trend in the period 1951-2015. The lowest precipitation level was recorded in 1954 (Kraków - $444 \mathrm{~mm}$, Bielsko-Biała - 568 $\mathrm{mm}$ ), while the highest precipitation was recorded in 2010 (Kraków $-1054 \mathrm{~mm}$, Bielsko-Biała - $1483 \mathrm{~mm}$ ).

On meteorological stations in Warsaw (Fig. 3) and Lublin there is upward trend of average annual air temperature, which is especially visible in the period 1981-2015. Annual precipitation sums display upward trend in the whole period 1951-2015. The highest precipitation took place in 201 (Warsaw $-751 \mathrm{~mm}$, Lublin $-829 \mathrm{~mm}$ ) while the lowest precipitation was recorded in 1976 (Warsaw - $304 \mathrm{~mm}$, Lublin $-367 \mathrm{~mm}$ ).

Meteorological station Chojnice has recorded a significant upward trend in average annual air temperature in the period 1951-2015, with particular growth in years 1981-2015 (Fig. 4). Annual precipitation sums display slight upward trend in the analyzed period, with particular growth in the last 35 years. The lowest precipitation was recorded in 1982 (Chojnice $-391 \mathrm{~mm}$, Torun - $346 \mathrm{~mm}$ ) and the highest - in 1980 (Chojnice - $849 \mathrm{~mm}$, Torun - $904 \mathrm{~mm}$ ).

In the analyzed period 1951-2015 there is a clear upward trend in average annual air temperature in all the meteorological stations selected as source of the data. That trend is particularly visible in the period 1981-2015. In the case of annual 
precipitation sums, a slight increasing trend or lack of it may be observed in the whole period 1951-2015.

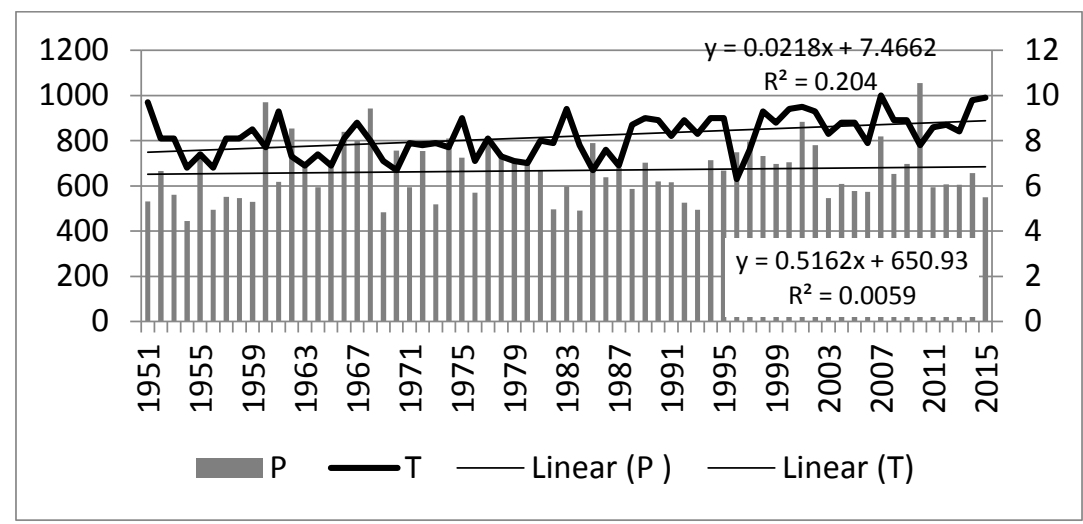

Fig. 2. Annual precipitation ( $P$ in $\mathrm{mm})$ and average air temperatures $\left(\mathrm{T}\right.$ in $\left.{ }^{\circ} \mathrm{C}\right)$ at meteorological station Kraków in years 1951-2015.

The results obtained for the selected 6 meteorological stations correspond with results obtained by other authors from greater number of meteorological stations located in the Vistula basin (Czarnecka and Niedzgorska-Lencewicz, 2012; Szwed, 2018).

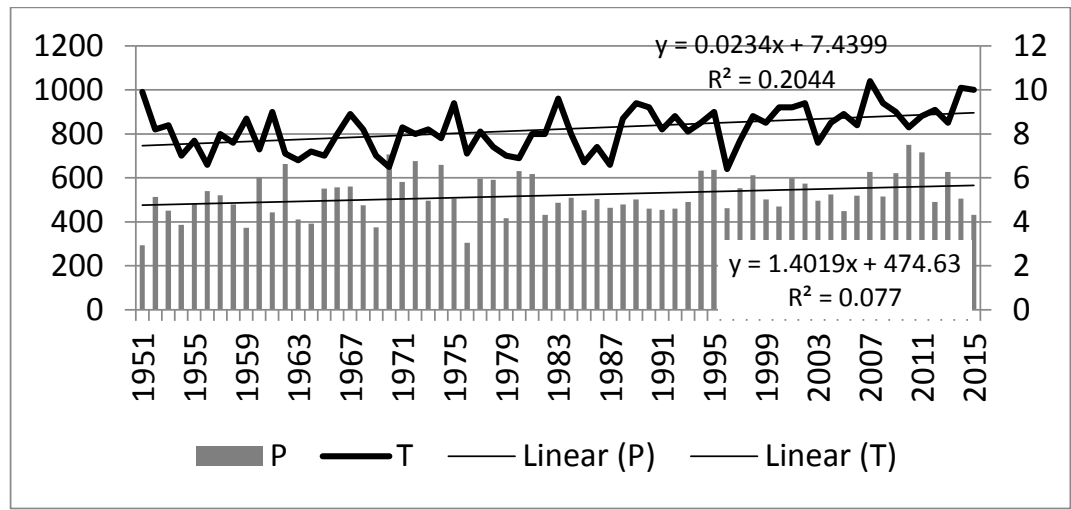

Fig. 3. Annual precipitation ( $P$ in $\mathrm{mm})$ and average air temperatures $\left(\mathrm{T}\right.$ in $\left.{ }^{\circ} \mathrm{C}\right)$ at meteorological station Warsaw in years 1951-2015.

\subsection{Variability of Vistula discharge in period 1951-2015}

The analysis of average annual discharge of Vistula is based on the data from 8 gauging stations located along the river. In the analyzed 65-year period, there is downward trend of maximum annual discharge values and upward trend of minimal annual discharge values in all the analyzed gauging stations.

The highest values of average annual discharge of Vistula occurred in 2010 on all gauging stations, except for Dęblin (maximum discharge was recorded in 1975). Flood of 2010 was caused by heavy rainfalls that took place in May and June in south-eastern part of the Vistula basin. They caused rapid water level increase on 
Vistula's tributaries and creation the flood wave on Vistula. The lowest annual discharge values in upper course of Vistula (apart from Szczucin) and middle course were recorded in 1984 and in the lower course (except from Włocławek) - in 1954, in which annual precipitation sums were low.

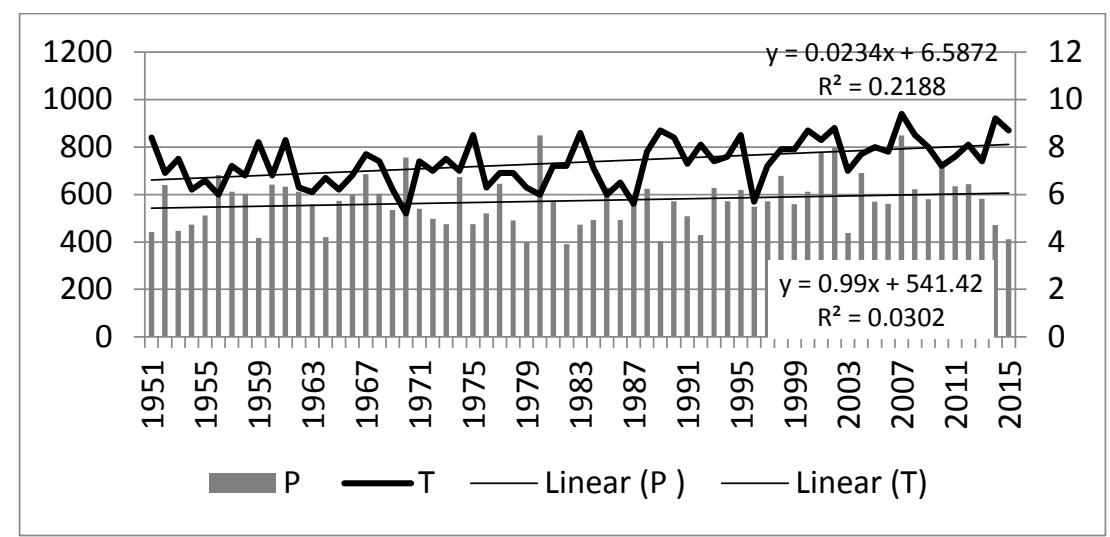

Fig. 4. Annual precipitation ( $P$ in $\mathrm{mm}$ ) and average air temperatures $\left(T\right.$ in $\left.{ }^{\circ} \mathrm{C}\right)$ at meteorological station Chojnice in years 1951-2015.

Comparison of annual Vistula's discharge variability on all gauging stations was possible thanks to usage of the index $\mathrm{k}$. Based on that index, there have been identified dry, wet and normal years of the analyzed period. The most wet were years 1975 (k between 1.44 and 1.75) and 2010 (k between 1.62 and 2.07), which was confirmed on all the stations. The driest in turn, were years 1954 (k between 0.62 and 0.70 ) and 1984 ( $\mathrm{k}$ between 0.56 and 0.75).

In the Table 3 it has been proven that in the whole period 1951-2015, dry and very dry years prevail over wet and very wet years. The exception is Tczew, where the numbers of wet and dry years are equal. The greatest prevalence of dry years over wet years occurred in the upper course of Vistula. The largest prevalence of years dry and extremely dry over wet and extremely wet ones occurs in the upper course of Vistula, while in the middle and lower course of the river the difference is smaller. The cause of such a state is river alimentation with underground water in the middle and lower course, which is especially visible during the drought periods.

\subsection{Annual indices of discharge variability}

On the basis of RBI index, there have been analyzed annual variability of Vistula's discharge in the whole period 1951-2015 (Fig. 5).

From 1969 to 2001, there is a significant increase (over 2 times) of the RBI at gauging stations Włocławek, Torun and Tczew. Since 2002 the RBI on lower Vistula gauging stations has been decreasing. The reason for such a behavior is change in work regime of hydropower plant in Włocławek from peak-period to run-of-river. That resulted in lack of rapid river discharge changes caused by the hydropower plant work system. Annual RBI index in the period 1951-2015 has a clear downwards trend in upper and middle course of river, while in the lower course there is a slight 
Table 3. Values of the $k$ index on gauging stations in years 1951-2015

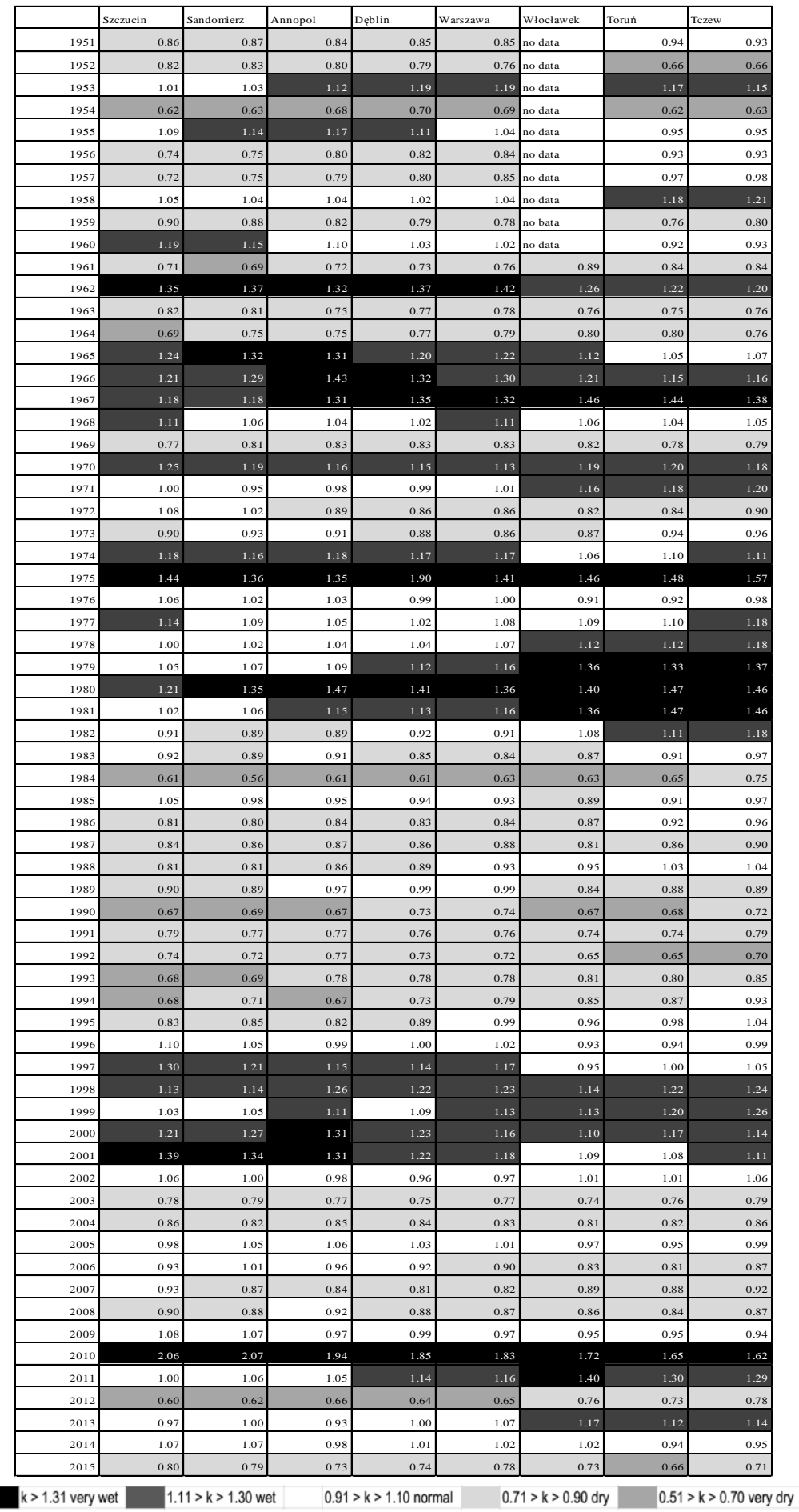


upward trend, statistically insignificant however. In turn, the analysis of annual $\mathrm{Cv}$ index in all gauging stations display a slight downward trend.

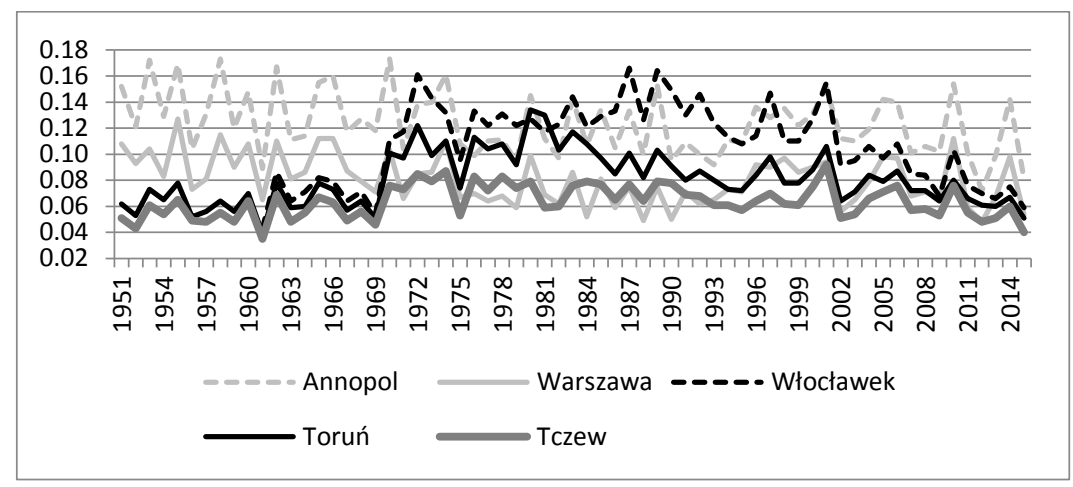

Fig. 5. Annual index of discharge variability RBI on selected hydrological stations in years 1951-2015

\section{CONCLUSIONS}

On the basis of the conducted analysis of precipitation and discharge in Vistula River basin it has been found that:

- Average annual air temperature in period 1951-2015 displays a clear upward trend on all analyzed meteorological stations, especially in the years 1981-2015.

- Average annual precipitation sums display a slight upward trend or lack of it in years 1951-2015. Only in meteorological stations Lublin and Warsaw, there have been statistically significant upward trend of precipitation, which is particularly visible in years 1981-2015.

- The values of average annual discharge of Vistula are even in years 1951-2015, with clear downward trend in years 1981-2015 as related to the periods 1951-2015 and 1951-1980. Multi-year period 1951-1980 characterized itself with higher discharges than the period 1981-2015.

- Discharges of Vistula characterize themselves with annual fluctuation of changes. In the analyzed period occurred both wet and dry years. The total number of dry years

$(\mathrm{k}<=0.9)$ prevailed more than 2 times over wet years $(\mathrm{k}>=1.11)$, which was particularly visible in the years 1981-2015. The highest quantity of dry years have been recorded in the upper course of Vistula ( 3 times as many dry years as the wet ones), and the lowest - in the lower course of Vistula.

The results achieved did not display a significant variability of average annual discharges of Vistula and of precipitation in the period 1951-2015, despite a considerable increase of average annual air temperature. Lack of a stable trend in discharge has been noted by Wrzesiński and Sobkowiak (2018). 
Further studies will include analysis of variability of monthly discharge of Vistula compared to variability precipitation volume and kind of precipitation in particular months. That will allow to explain the causes of discharge variability.

\section{REFERENCES}

1. Alfieri L., Dottori F., Betts R., Salamon P., Feyen L. (2018), Multi-model projections of river flood risk in Europe under global warming. Climate, 6, 16. DOI: 10.3390/cli6010016.

2. Baker D.B., Richards R.P., Loftus T.T., Kramer J.W. (2004), A new flashiness index: characteristics and applications midwesterns rivers and streams. Journal of the American Water Resources Association, 503-522.

3. Barbalić D., Kuspilić N. (2014), Trends of indicators of hydrological alterations. Gradevinar, 66, 7, 613-624. DOI: 10.14256/JCE.1003.2014.

4. Bormann E. (2010), Runoff regime changes in German rivers due to climate change. Erkunde, 64, 3, 257-279.

5. Czarnecka M., Niedzgorska-Lencewicz J. (2012), Wieloletnia zmienność sezonowych opadów w Polsce. Woda-Środowisko-Obszary Wiejskie, 12, 2, 45-60.

6. Dobrovol'skii S.G. (2018), Incorporating natural changes in global climate in verylong-range forecasting of river runoff. Water Resources, 45 (4), 437-446.

7. Gailiušis B., Kriaučiūnenè J., Jakimavičius D., Šarauskienė D. (2011), The variability of long-term runoff series in the Baltic Sea drainage basin. Baltica, 24, 1, 45-54.

8. Hanel, M., Vizina, A., Máca, P., Pavlásek, J. (2012), A multi-model assessment of climate change impact on hydrological regime in the Czech Republic, J. Hydrol. Hydromech., 60, 3, 152-161. DOI: 10.2478/v10098-012-0013-4.

9. Holko L., Parajka J., Kostka Z., Skoda P., Bloschl G. (2011), Flashiness of mountain streams in Slovakia and Austria. Journal of Hydrology, 405, 392-401.

10. Jokiel P., Stanisławczyk B. (2012), Roczne odpływy maksymalne i minimalne w dorzeczach Odry i Wisły w przekroju wieloletnim. Czasopismo Geograficzne, 83, 3, 133-143.

11. Kędra M. (2017), Altered precipitation and flow patterns in the Dunajec River Basin. Water, 9, 22. DOI:10.3390/w9010022

12. Kļaviņš M., Rodinov V., Timukhin A., Kokorīte I. (2008), Patterns of river discharge: long-term changes in Latvia and the Baltic region. Baltica, 21, 41-49.

13. Kliment Z., Matoušková M. (2008), Long-term trends of rainfall and runoff regime in Upper Otava River basin, Soil and Water Research, 3, 155-167.

14. Královec V., Kliment Z., Matoušková M. (2016), Evaluation of runoff response on the basis of a comparative paired research in mountain catchments with the different land use. Case study of the Blanice River, Czechia. Geografie, 121, 2, 209-234.

15. Kubiak-Wójcicka K. (2018), Flow characteristics of the Vistula River at the Tczew gauging station in 1951-2010 based on Flashiness Index. 4rd International Conference Water Resources and Wetlands, 5-9 September 2018 Tulcea (Romania), ed. P. Gastescu, P. Bretcan, 119-129.

16. Kubiak-Wójcicka K., Bąk B. (2018), Monitoring of meteorological and hydrological droughts in the Vistula basin (Poland). Enviromental Monitoring and Assesment, 190, 11, 1-16. DOI: 10.1007/s10661-018-7058-8. 
17. Kundzewicz Z.W., Robson A.J. (2004), Change detection in hydrological records-a review of the methodology. Hydrological Sciences Journal, 49, 1, 7-19. DOI: 10.1623/hysj.49.1.7.53993.

18. Orešić D., Čanjevac I., Maradin M. (2017), Change in discharge regimes in the middle course of the Sawa river in the 1931-2010 period. Prace Geograficzne, 151, 93-119. DOI: $10.4467 / 20833113$ PG.17.024.8036.

19. Osuch M., Romanowicz R.J., Lawrence D., Wong W.K. (2016), Trends in projections of standardized precipitation indices in a future climate in Poland. Hydrol. Earth Syst. Sci., 20, 1947-1969. DOI: 10.5194/hess-20-1947-2016

20. Pekarova P., Miklanek P., Pekar J. (2006), Long-term trends and runoff fluctuations of European rivers. Climate Variability and Change - Hydrological Impacts (Proceedings of the Fifth FRIEND World Conference held at Havana, Cuba, November 2006), IAHS Publ.

21. Pfeiffer M., Ionita M. (2017), Assessment of Hydrologic Alterations in Elbe and Rhine Rivers, Germany, Water, 9, 684. DOI: 10.3390/w9090684.

22. Piniewski M., Marcinkowski P., Kundzewicz Z.W. (2018), Trend detection in river flow indices in Poland. Acta Geophysica, 66, 347-360. DOI: https://doi.org/10.1007/s11600-018-0116-3.

23. Romanescu Gh., Zaharia C. (2016), Variation of mean seasonal discharges in the Miletin River basin (Moldavian Plain, Romania). PESD, 10(1), 61-79. DOI: 10.1515/pesd-2016-0006.

24. Sánchez-Chóliz J., Sarasa C. (2015), River flows in the Ebro Basin: A centuary of evolution, 1913-2013. Water, 7, 3072-3082. DOI:10.3390/w7063072.

25. Stahl K., Hisdal H., Hannaford J., Tallaksen L.M., van Lanen H.A.J., Sauquet E., Demuth S., Fendekova M., Jódar J. (2010), Streamflow trends in Europe: evidence from a dataset of near-natural catchments. Hydrol. Earth Syst. Sci., 14, 2367-2382. DOI:10.5194/hess-14-2367-2010.

26. Stonevičius E., Valiuškevičius G., Rimkus E., Kažys J. (2014), Climate induced changes of Lithuanian Rivers runoff in 1960-2009, Water Resources, 41(5), 592-603. DOI: $10.1134 /$ S0097807814050133.

27. Szwed M. (2018), Variability of precipitation in Poland under climate change. Theoretical and Applied Climatology. DOI: https://doi.org/10.1007/s00704-018-2408-6.

28. Szwed M., Karg G., Pińskwar I., Radziejewski M., Graczyk D., Kędziora A., Kundzewicz Z. W. (2010), Climate change and its effect on agriculture, water resources and human health sectors in Poland. Nat. Hazards Earth Syst. Sci., 10, 1725-1737. DOI: 10.5194/nhess-10-1725-2010.

29. IPCC (2013) Climate change. The physical science basis. In Contribution of Working Group I to the 5th Assessment Report of the Intergovernmental Panel on Climate Change; Cambridge University Press: Cambridge, UK; New York, NY, USA, 2013.

30. Wrzesiński D., Sobkowiak L. (2018), Detection of changes in flow regime of rivers in Poland. J. Hydrol. Hydromech., 66, 1, 55-54. DOI: 10.1515/johh-2017-0045. 